\title{
Causes and Impacts of Deforestation and Forest Degradation at Duguna Fango Woreda
}

\author{
Aklilu Bajigo Madalcho ${ }^{1,}$, , Merkineh Mesene Mena ${ }^{1}$, Barana Babiso Badeso ${ }^{2}$ \\ ${ }^{1}$ Natural Resource Management Department, College of Agriculture, Wolaita Sodo University, Wolaita Sodo, Ethiopia \\ ${ }^{2}$ Geography and Environmental Studies Department, College of Social Science and Humanities, Wolaita Sodo University, Wolaita Sodo, \\ Ethiopia
}

\author{
Email address: \\ bajigoaklilu05@gmail.com (A. B. Madalcho), merkinehmsn20@gmail.com (M. M. Mena), babieamado@gmail.com (B. B. Badeso) \\ ${ }^{*}$ Corresponding author
}

\section{To cite this article:}

Aklilu Bajigo Madalcho, Merkineh Mesene Mena, Barana Babiso Badeso. Causes and Impacts of Deforestation and Forest Degradation at Duguna Fango Woreda. International Journal of Natural Resource Ecology and Management. Vol. 5, No. 1, 2020, pp. 14-25.

doi: $10.11648 /$ j.jijnrem.20200501.13

Received: February 18, 2020; Accepted: March 4, 2020; Published: March 17, 2020

\begin{abstract}
Forest is one of the crucial resources that determine the livelihood, environmental stability, and socio-cultural value of the dependent people. However, being deteriorated by different drivers it is becoming a global agenda with deeprooted implications following the massive forest clearance and deterioration. This research was conducted to diagnose the causes of deforestation and forest degradation and to devise the ways for vegetation cover improvement opportunities at Duguna Fango Woreda. With a random sampling approach, ten districts (commonly named as Kebeles) were selected, and proportionate sample distribution was made to each kebele. A total of 120 household heads were interviewed with a structured questionnaire. Focus group discussion, field observation, and secondary data sources were used for qualitative data requirements. The quantitative data were analyzed by using SPSS software (version 20.0); descriptive and inferential statistics were computed. Pearson correlation, Ordinal logistic regression; and chi-square test (crosstabulation) were computed for different variables. Accordingly, Slash and burn, farmland expansion, overgrazing, timber logging, firewood collection, charcoal production, forest fire, and settlement expansion were identified as direct causes of deforestation at $95 \%$ CI. On the other hand, population growth, increased price of forest products, climate change, and lack of awareness on forest management were indirectly positively correlated with deforestation in the area. Consequently, it has resulted in the loss of biodiversity, soil fertility decline, frequent drought occurrence, erratic rainfall; local temperature increment, and gully formation due to soil erosion at $95 \%$ CI. Selected Agroforestry practices are identified as the ideal solution to the current deforestation problem at Duguna Fango woreda.
\end{abstract}

Keywords: Deforestation, Duguna Fango, Environmental Change, Forest

\section{Introduction}

According to the [1], the forest is defined by the presence of trees with land covering more than 0.5 ha. The trees should be able to reach a minimum height of $5 \mathrm{~m}$ in situ and a canopy cover of at least $10 \%$. Following the FAO definition, in February 2015 Ethiopia adopted a new forest definition as follows: "Land spanning at least 0.5 ha covered by trees and bamboo), attaining a height of at least $2 \mathrm{~m}$ and a canopy cover of at least $20 \%$ or trees with the potential to reach these thresholds insitu in due course" [2]. In the recent forest proclamation of Ethiopia (No. 542/2007), high forests, woodlands, plantations, bamboo forests are recognized as forests.

The recent data on forest resources of Ethiopia reported in [3] puts Ethiopia among countries with forest cover of 10 to $30 \%$. According to this report, Ethiopia's forest cover is 12.2 million ha $(11 \%)$. It further indicated that the forest cover decline from 15.11 million ha in 1990 to 12.2 million ha in 2010, which is $2.65 \%$ of the forest cover loss. Forest resources in Ethiopia have experienced so much pressure due to increasing need for wood products and conversion to agriculture. Conversely, it is now experiencing continuous 
destruction of forest resources due to overexploitation, deforestation, land degradation, climate change, and pollution.

Despite the availability of many good practices, land uses in Ethiopia lacking plan to ensure social and economic suitability and safeguard natural resources. Lack of coordination among the various sectors of the economy such as agriculture, forest, livestock, water resources, energy and mining, and wildlife and tourism, is causing severe degradation of natural resources, and worsening food insecurity. The weak implementation capacity of policies related to natural resources including forests, lack of a strong forest institution, and discrepancy among sectorial policies (investment/settlement vis-à-vis forestry) remain a challenge in the country. In the meantime, climate change adds a further pressure on many ecosystems and people already negatively impacted by pollution, deforestation and land degradation. Loss of the services that ecosystems provide is also a significant barrier to the achievement of the Country's vision.

Deforestation has also been noted to contribute tremendously to long-term environmental consequences like global warming, biodiversity loss and soil degradation [4]; in that people are forced to migrate, exploring new forest frontiers increasing deforestation [5, 6, 7]. Based on this analysis, deforestation posits a challenge for the practice of sustainable forest management, which focuses on balancing environmental benefits and development of livelihoods for the rural poor so that deforestation can be avoided in the long term. The trend in Ethiopia today is to protect the remaining natural forests and expand the woody vegetation cover for their various social, economic and environmental values. In line with this, the current study focused on assessing causes of deforestation and forest degradation to look for the forest development opportunities at Duguna Fango Woreda.

The dynamics and causes of deforestation and forest degradation are multi-faceted, complex and vary from place to place. Generally speaking, the drivers can be described as direct and underlying causes. In reality, there are long, complex chains of causation that can bring about deforestation or the degradation of forests. Hence, carefully and systematically analyzing and comprehensively addressing all direct and underlying drivers of deforestation and forests degradation are the priority and key prerequisite to effectively reducing local and global problems from deforestation and forest degradation. Measures and strategies to address drivers should seek to harmonize different development objectives such as the need for increased food production; livelihoods improvements, climate change mitigation and adaptation, and enhanced environmental conservation [8-10].

Duguna Fango woreda is covering a varying altitudinal gradient with historically diversified species forest cover on communal and privately owned lands before the current forest cover status reached up. Consequently, limited access of forest product supplies, erosion hazards, gulley formation, failure on agricultural sector (animal and crop productivity) and expansion of large portion of unproductive lands are becoming common impacts of the land degradation in the area. Due to this situation, the woreda was chosen by the Ministry of Environment, Forest and Climate change of Ethiopia for implementation of the project entitled "Integrated Land scape management to enhance food security and ecosystem resilience" that was funded by GEF, UNDP, and GOE for the period of 2017 up to 2022. Although multifaceted driving factors are expected to be contributing to deforestation and forest degradation in the woreda, there was no sufficient and empirical data available to clearly indicate direct and underlying drivers of deforestation and forest degradation in the woreda. This affects the decision of intervention to reverse the worsening situation of forest loss in the woreda. Therefore, this study was conducted to assess the causes and impacts of deforestation and forest degradation to devise the way for forest cover enhancement opportunities Woreda.

\section{Research Methods}

\subsection{Study Site Description}

Duguna Fango woreda is located at $42 \mathrm{~km}$ east from the zone city named Wolaita Sodo, and $73 \mathrm{~km}$ south west from Hawassa which is a capital city of Southern Nations, Nationalities, and Peoples' Region of Ethiopia; and $300 \mathrm{~km}$ south of Addis Ababa. Astronomically, the woreda is located at $6^{0} 45^{\prime} 00^{\prime \prime}-7^{0} 5^{\prime} 00^{\prime \prime} \mathrm{N}$ Latitude and $37^{0} 58^{\prime} 00^{\prime \prime}-38^{0} 8^{\prime}$ 00" E Longitude (Figure 1). It is part of the Wolayita Zone located in the western edge of Great Rift Valley [11].

The woreda is known for its undulating topography and diversified land features with mountains, valley and platue land forms [12]. The woreda lies between 1,303 and 2318 masl, and is dominated by lowland with hot climate of $73 \%$ of the total area coverage followed by the $27 \%$ highland (cold climate) [13]. The woreda covers a total of 46,660 ha of land, and farm sizes are generally small, i.e., about 0.5 ha per head. The land use patterns in the woreda include forest land, grazing land, cultivation, and settlement areas. Small scale rain fed subsistence agriculture is the dominant base of economy in the Woreda although there is few irrigation based agriculture practices is taking place along with the Bilate river sides. Based on the agroecological suitability, maize, wheat, barley, and teff are commonly grown crops in the woreda. Similarly, cattle, goat, sheep and donkeys are the major animal types kept by households at different altitudinal ranges. 


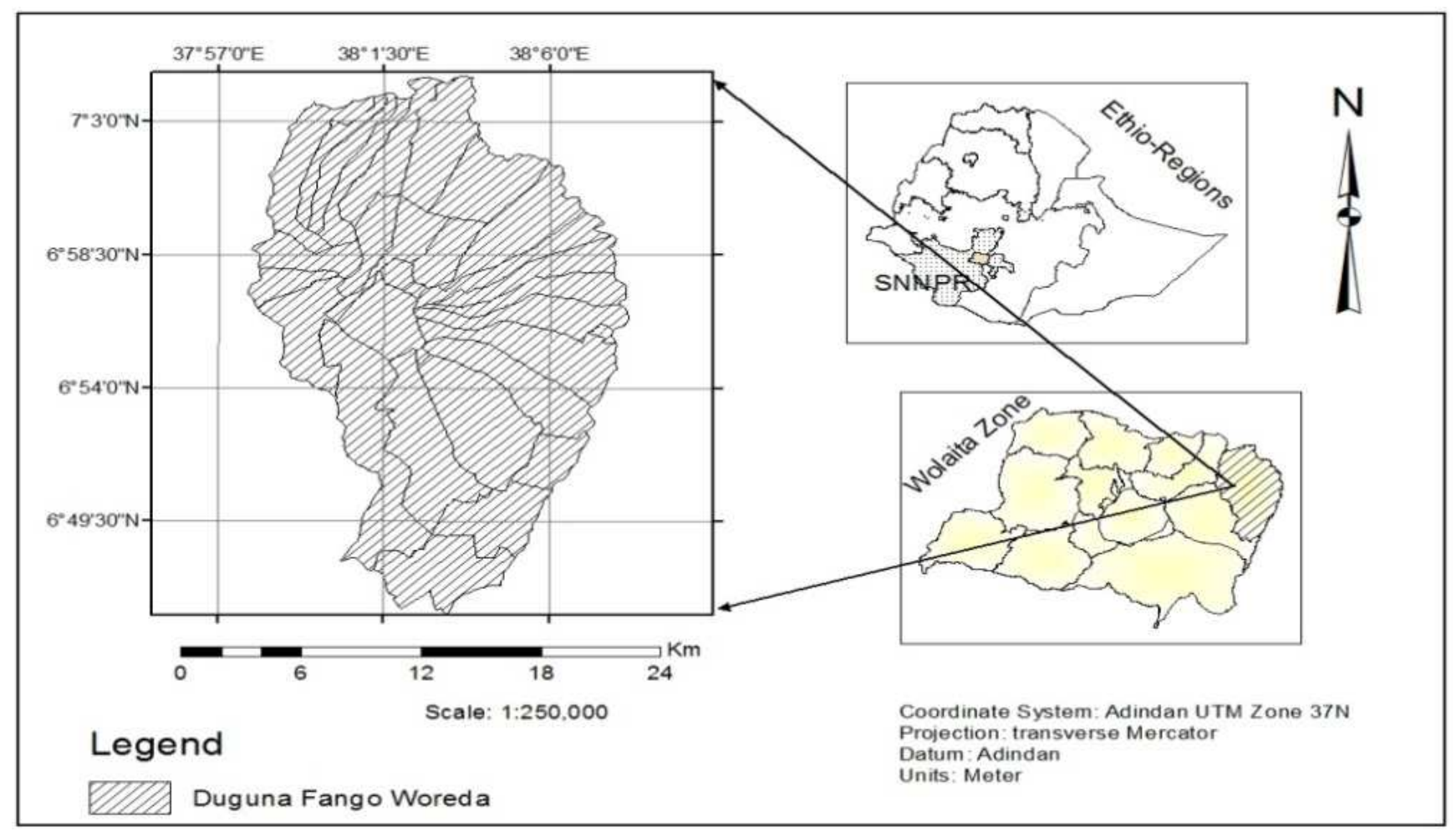

Figure 1. Map of the Study area.

\subsection{Research Design and Sample Size Determination}

The study was designed to assess the direct and underlying causes of deforestation and forest degradation in Duguna Fango woreda by using socio-economic survey with cross sectional data was employed. Multistage sampling procedures were employed; the woreda selected purposively due to the reason that the forest loss and deterioration is considerable problem. Since the study population was homogeneous on the subject matter, ten kebeles were selected by using simple random sampling method. The proportion of total sample to each kebele was distributed according to the population proportion formula. Then with simple random sampling technique, household heads were selected from each kebele to have the total sample size of 120 based on [14] as in Equation 1. Structured questionnaire, focus group discussion, and field observation were used to collect primary data; and office reports and published documents were used for secondary data collection.

$$
n=\frac{z^{2} \cdot p \cdot q \cdot N}{e^{2}(N-1)+z^{2} \cdot p \cdot q}
$$

Where, $\mathrm{n}=$ sample size $\mathrm{z}=$ the value of standard variate at a given confidence level and to be worked out from table showing area under normal curve, $\mathrm{p}=$ sample proportion, $\mathrm{q}=$ $1-\mathrm{p}, \mathrm{e}=$ given precision rate or acceptable error, $\mathrm{N}=$ population.

The desired precision rate or acceptable error is assumed to be \pm 9 i.e. we can say $\mathrm{e}=9 \%$ or $0.09, \mathrm{z}=1.96$ (desired confidence level is $95 \%$ and value obtained from table) $\mathrm{p}=$ 0.5 (sample proportion). $\mathrm{q}=0.5\{(1-0.5)$ i.e $1-\mathrm{p}\}$.
Accordingly, a total of 120 respondents were selected based on the total population size of 10 kebeles $(\mathrm{N}=45198)$.

\subsection{Data Collection}

Primary data on the socio-economic aspects was collected through structured questionnaire survey, focus group discussions and field observation. Through structured questionnaire, livelihood sources, their perception on forest management, deforestation and forest resource degradation situation, and the driving factors, the impacts of deforestation and forest deterioration was assessed. Trained enumerators were used to handle the required survey data collection. To triangulate the survey data, and to have in depth impression on the case, focus group discussionen (FGD) was used. One FGD was held in each kebele with each group containing 10 members that composed $50 \%$ of women. Checklist based field observation was carried to have the researcher view on the existing situation of deforestation and forest degradation. Furthermore, secondary data from official documents and available literatures were collected for different qualitative and quantitative data needs on perception of local people on forest management, causes of deforestation and forest degradation, and locally available solutions for the current problem.

\subsection{Data Analysis}

The socio-economic quantitative data was analyzed by using SPSS software (version 20.0). Descriptive statistics such as percent and frequency, and inferential statistics was computed according the data type. One-tiled bivariate Pearson correlation analysis was computed for the variables 
that directly cause deforestation and forest degradation Vs its effects at 99\% and 95\% CI. Linear and Ordinal logistic regression analysis were computed for the respective data sets at 95\% CI. Chi-square test (crostabulation) at 95\% CI was computed for the association between variables. Qualitative data collected through field observation, FGD, and secondary document review were narrated, and explained logically based on the existing conditions and literatures.

\section{Result and Discussion}

\subsection{The socio-economic Drivers of Deforestation and Forest Degradation}

\subsubsection{Socio-demographic Characteristics of the Respondents}

The socio-demographic characteristics are presented in the Table 1 . About $88.3 \%$ of the respondents were men, while the rest were women. Almost all, $98.3 \%$ of the respondents were married. About $85 \%$ of the respondents were with the age of above 34 years old. This age class is socially responsible, able to understand the environment so that can respond the question with mature mind. Regarding the education status, $65.9 \%$ of the respondents were with junior school and below it, while significant figure, almost $34.2 \%$ of this category is illiterate. Illiteracy may be directly responsible to the lower awareness status to the sustainable natural resources management. In addition, the average household family size is 7 , and exhibiting the area is densely populated. The data shows that deforestation and forest degradation may be influenced by these socio-demographic characteristics of sampled households differently.

Table 1. Descriptive statistics of socio-demographic characteristics.

\begin{tabular}{|c|c|c|c|}
\hline Variables & Categories & Frequency & Percent (\%) \\
\hline \multirow{3}{*}{ Sex } & Male & 106 & 88.3 \\
\hline & Female & 14 & 11.7 \\
\hline & Total & 120 & 100.0 \\
\hline \multirow{3}{*}{ Marital status } & Married & 118 & 98.3 \\
\hline & Unmarried & 2 & 1.7 \\
\hline & Total & 120 & 100.0 \\
\hline \multirow{7}{*}{$\begin{array}{l}\text { Educational } \\
\text { level }\end{array}$} & Illiterate & 41 & 34.2 \\
\hline & Primary school & 23 & 19.2 \\
\hline & Junior school & 29 & 24.2 \\
\hline & Secondary school & 19 & 15.8 \\
\hline & TVT/Diploma & 5 & 4.2 \\
\hline & $>=$ Degree & 3 & 2.5 \\
\hline & Total & 120 & 100.0 \\
\hline \multirow{6}{*}{ Age } & $18-25$ & 2 & 1.7 \\
\hline & $26-33$ & 16 & 13.3 \\
\hline & $34-41$ & 35 & 29.2 \\
\hline & $42-49$ & 24 & 20.0 \\
\hline & $>50$ & 43 & 35.8 \\
\hline & Total & 120 & 100.0 \\
\hline
\end{tabular}

However, from all the socio-demographic variables included in this study, sex of the respondents $(\mathrm{P}=0.001$, $\chi 2=13.76)$, family size $(\mathrm{P}=0.002, \chi 2=55.03)$, and education level $(\mathrm{P}=0.005, \chi 2=25.23)$ were identified as significantly associated to the forest status of the study area at $95 \% \mathrm{CI}$ (Table 2). Male headed households have high chance of engagement in the exploitation of forest resources unsustainably through charcoal production and fuelwood collection from communal forest land since they have better muscular endurance. Similarly, with lower education status, and illiterate community their perception to forest management and the knowledge of economic and environmental impact of deforestation and forest degradation is expected to be at low level. This may be the reason for the strong association between the respondent's education status and deforestation and forest degradation in the woreda. The family size of the study area is influenced the forest negatively, and this is mostly true as the large family size leads to the high level of dependency on the forest products, and other land use demand in the expense of natural forest (Figures 2 and 3).

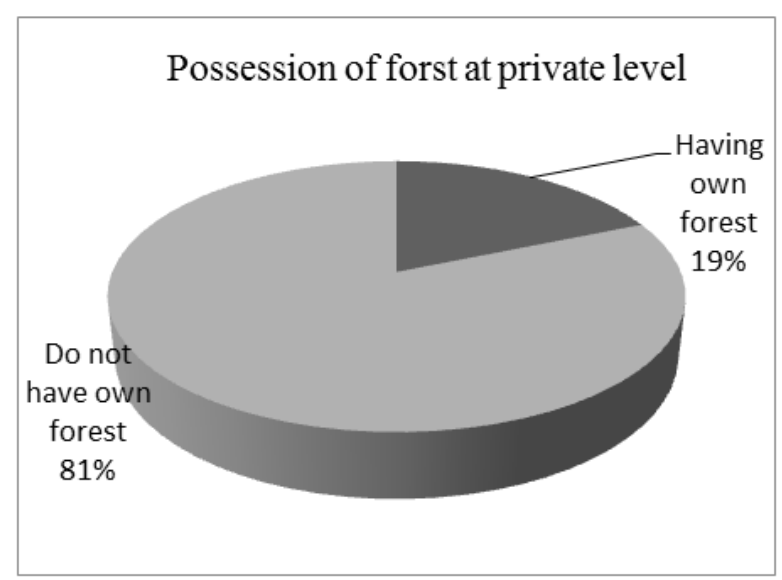

Figure 2. The respondents with privately owned forests.

\section{Comunal land forest utilization \\ Use communal forest for free \\ Do not use communal forest for free}

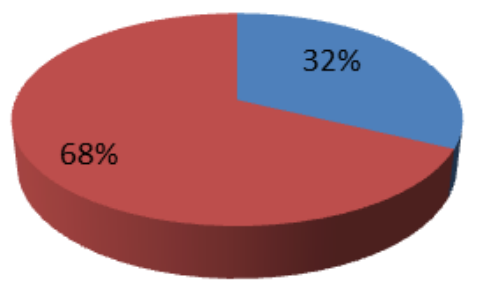

Figure 3. The dependency of the respondents on communal land forested resources. 
Table 2. Chi-square test for socioeconomic factors association with deforestation.

\begin{tabular}{|c|c|c|c|c|}
\hline Variables & Chi-Square Tests & Value & Df & Sig.(2-sided) \\
\hline \multirow{3}{*}{ Sex of household head } & Pearson $\chi^{2}$ & $13.755^{\mathrm{a}}$ & 2 & 0.001 \\
\hline & Likelihood Ratio & 11.458 & 2 & 0.003 \\
\hline & Linear-by-Linear Association & 12.978 & 1 & 0.000 \\
\hline \multirow{3}{*}{ Family size } & Pearson $\chi^{2}$ & $55.034^{\mathrm{a}}$ & 28 & 0.002 \\
\hline & Likelihood Ratio & 51.802 & 28 & 0.004 \\
\hline & Linear-by-Linear Association & 1.951 & 1 & 0.162 \\
\hline \multirow[t]{2}{*}{ Educational level } & Likelihood Ratio & 27.371 & 10 & 0.002 \\
\hline & Linear-by-Linear Association & 0.041 & 1 & 0.840 \\
\hline
\end{tabular}

\subsubsection{Socio-economic Characteristics of the Sample Respondents}

The data in Table 3 shows that main livelihood option of the respondents is crop-animal mixed farming system (95.8\%), while crop cultivation takes the highest share (50\%). It can be understood that the steadily increasing population, agricultural land encroachment and settlement expansion in the expense of natural forest is inevitable in the study area followed by the nature livelihood. Similar report shows that forests clearance and the subsequent agricultural development have a detrimental effect on every element of local ecosystems as cited in [15].

Large number of the respondents indicated as they further clear the remnant patch of forest for sufficient crop production. The declining crop productivity due to visible form of soil erosion, loss of organic layer, and climate change are exerting extra stress on the farming system and pushes the farmers to expand the cultivated farmland size. Hence, $32.5 \%$ of the respondents agree that there is forest clearance for crop cultivation in the last 10 years (Table 4 ).

Table 3. Major income sources and dominant agricultural activities in the woreda.

\begin{tabular}{lllll}
\hline Household Income sources & Frequency & \% & Dominant agriculture & Frequency \\
\hline Crop-animal mixed farming & 115 & 95.8 & Crop cultivation & 60 \\
Charcoaling from natural forest & 2 & 1.7 & Animal production & 11 \\
Off-farm activity & 3 & 2.5 & Mixed farming & 49 \\
Total & 120 & 100.0 & & \\
\hline
\end{tabular}

On the other hand, Table 4 depicts that the animal management is not in a way that can support forest resource conservation. Management of household animals have meaningful effect on the forest in that the animals browse and tramples the seedlings, and saplings, affects the soil seed bank, and facilitates soil erosion. In the study area, $35 \%$ of the respondents agree that the animals were kept in communal land, while $31.7 \%$ of the respondents set their domestic animals freely to move anywhere specially at dry season. This gives us a clue how much these animals can bring destruction on the forest in the last decades.

Table 4. The influence of animal management and crop cultivation on forest resources.

\begin{tabular}{lll}
\hline & Frequency & Percent \\
\hline Animal grazing and feeding places & & \\
Communal land grazing & 42 & 35.0 \\
In captivity at home/cut-and carry system & 28 & 23.3 \\
Free grazing anywhere & 38 & 31.7 \\
Rotational grazing & 12 & 10.0 \\
Total & 120 & 100.0 \\
Source of land access for crop cultivation & & \\
Renting from neighbors & 11 & 9.2 \\
Clearing nearby remnant forest & 39 & 32.5 \\
Reclaiming degraded land & 12 & 10.0 \\
Inheritance from family & 58 & 48.3 \\
Total & 120 & 100.0 \\
\hline
\end{tabular}

\subsubsection{Socio-economic Role of Forests and Its Current}

\section{Status in the Woreda}

From the total respondents, only $18.75 \%$ have their own forest in the form of woodlots and very patchy woodlands, while the rest $81.3 \%$ do not possess their own forest (Figure 2 ). This indicates how much the forest resource related provisions are in short fall for the study area. The data from personal observation and focus group discussants indicated that there are serious shortage of wood products including construction and fuelwood. On the other hand, due to the commencement of the efforts of area closure on some mountains with communal property regime, freely utilization of forest products is restricted in the woreda.

However, $32.2 \%$ of respondents are still illegally utilize the degraded forests in communal land for collection of firewood, charcoaling, grazing and browsing, collection of medicine, and other household utensils although there is restriction (Figure 3). To bring back the current forest status of the woreda, expansion of reforestation and afforestation programs primarily at the privately owned lands, then to satisfy the household level forest products, and services demand is very important. While making the communal land restoration and protection efforts in its high commitment, it capacitates the local people to have their own trees and shrubs for the provision of wood and non-wood forest products which they have used to collect from natural forest other ways. On the other hands, intervention of human and animal activity for harvesting the wood and none wood forest 
products has to be controlled until recommended time.

The forest utilization pattern of Duguna Fango woreda is mainly relays on the remnant natural forest from the communal land uses. The community utilizes forest products for different purpose as a means of livelihood. Mainly the forest was, and is being harvested for timber (T), fuel wood $(\mathrm{F})$, construction wood $(\mathrm{CW})$, animal fodder (AF), herbal medicine (HM), household utensils (HHU), animal browsing and grazing $(\mathrm{AB})$, and charcoal production $(\mathrm{Ch})$ for household consumption and income generation purpose
(Figure 4). The entire forest harvesting objective in the study area is focus on satisfying household wood and none-wood forest products demand rather than that of income generation except for the case of charcoal production. Charcoaling activity is the most destructive forest utilization approaches carried out in the woreda with illegal loggers for income generation. The focus group discussion was indicated that the known indigenous trees and shrub species used for charcoal production were from family of Cuspidate, Fabaceae, and many other indigenous tree and shrub species (Figure 5).

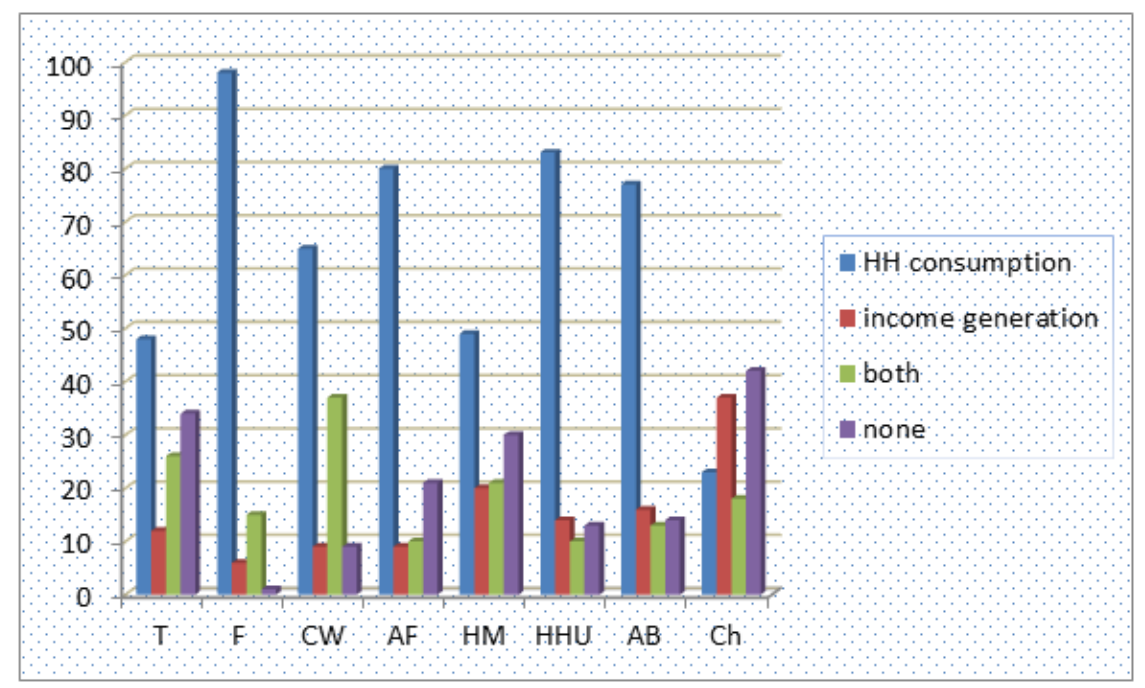

Figure 4. The forest resources utilization pattern in the woreda.

Where ' $\mathrm{T}$ ' for timber, ' $\mathrm{F}$ ' for fuel wood, ' $\mathrm{CW}$ ' for construction wood, 'AF' for animal fodder, ' $\mathrm{HM}$ ' for herbal medicine, 'HHU' for household utensils, 'AB' for animal browsing and grazing and ' $\mathrm{Ch}$ ' for charcoal production.

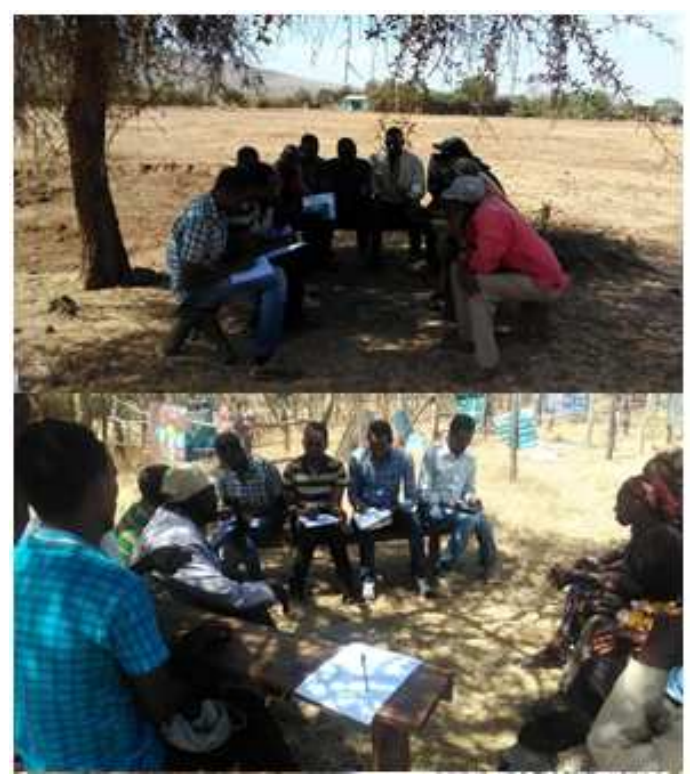

Figure 5. Focus group discussions carried out in study sites.

According to the researchers' field observation and focus group discussion, except the cut-off stamps and degraded and crooked saplings that have been browsed, majority of the precious indigenous plant species in communal land were lost over. The worst scenario is that the illegal charcoal makers uproot the stamps of indigenous tree species in communal and privately owned land for charcoal production. Through this trend of forest and forestland utilization for both household consumption and income generation activities, the environmental sustainability, food security, and climate change resilience of the woreda were becoming under question, and need urgent response. This was the reason for implementing the national project entitled "Integrated Land Management to Enhance Food Security and Ecosystem Resilience" through UNDP fund since 2017 GC. Hence, the project is energetically started to implement targeting on forest restoration scheme, and paradigm shift on the income generation schemes with all limitations in its scope and magnitude of working towards the alarming problem.

\subsubsection{Direct Causes of Deforestation}

The FGD data in the study area indicated that around 1977 s, majority of the land in the woreda was covered with dense forest. Whereas, due to misunderstanding and lack of awareness to manage natural forest, population growth, loosened customary rules on forest resources following the fall of Derg regime, and the subsequent unmanaged forest utilization the forest of woreda was lost. The respondent's perception on deforestation and forest degradation is expressed in different levels in study area. As a result, $40.45 \%$ 
were very strongly agree, $12.56 \%$ were strongly agree, $13.18 \%$ were moderately agree, and $33.72 \%$ were not agree as deforestation and forest degradation has been happening in study area.

On the other hand, the direct driving forces of deforestation and forest degradation on the study area shown that slash-burn, farmland expansion, overgrazing, timber logging, firewood collection, infrastructure construction, charcoal production, forest fire, mining, and settlement (Figure 6). Timber production may have to be balanced against the role of forest as a protection of erosion and pollution, as a wilderness or wildlife refuge, or as a recreational area [16]. It also depicts the level of respondent's agreement on these variables as it influenced deforestation and forest degradation in the study area.

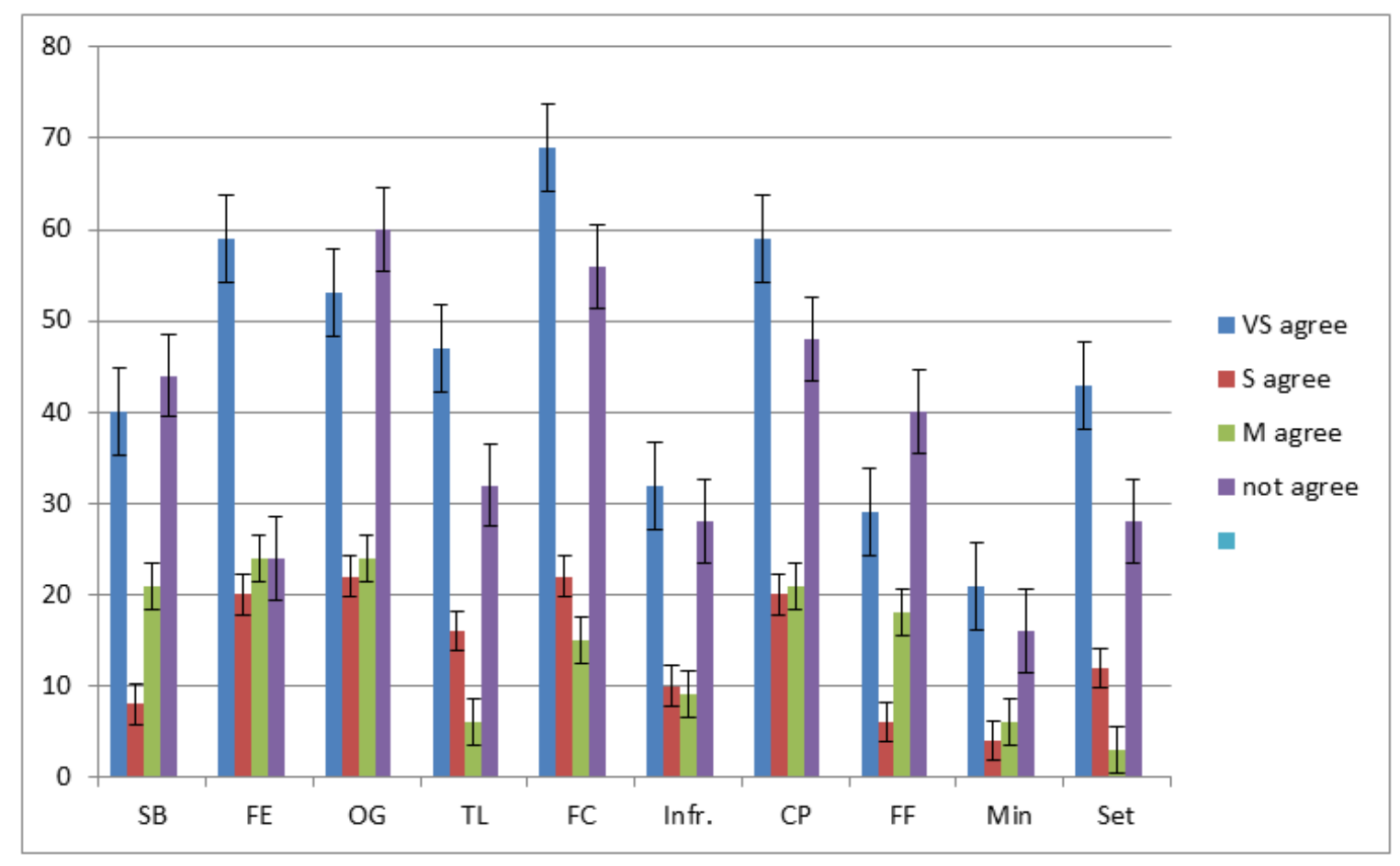

Figure 6. Direct drivers of deforestation and the level of community perception.

Where SB is for slash and burn, FE for farmland expansion, OG for overgrazing, TL for timber logging, FC for firewood collection, Infr. For infrastructure construction,
$\mathrm{CP}$ for charcoal production, FF for forest fire, Min for mining, and Set for settlement; VS agree for very strongly agree, S agree for strongly agree, $\mathrm{M}$ agree for moderately agree.

Table 5. Pearson Chi-Square Tests with weighted cross tabulation for direct causes of deforestation.

\begin{tabular}{|c|c|c|c|}
\hline Variables & Value & Df & Asymp. Sig. (2-sided) $(\mathrm{P}>0.05)$ \\
\hline Slash and burn & $15.594^{\mathrm{a}}$ & 3 & 0.001 \\
\hline Farmland expansion & $68.270^{\mathrm{a}}$ & 3 & 0.000 \\
\hline Livestock grazing & $15.465^{\mathrm{a}}$ & 3 & 0.001 \\
\hline Timber logging & $17.877^{\mathrm{a}}$ & 3 & 0.000 \\
\hline Fire wood collection & $19.468^{\mathrm{a}}$ & 3 & 0.000 \\
\hline Infrastructure & $1.784^{\mathrm{a}}$ & 3 & 0.618 \\
\hline Charcoal production & $16.393^{\mathrm{a}}$ & 3 & 0.001 \\
\hline Forest fire incidences & $14.439^{\mathrm{a}}$ & 3 & 0.002 \\
\hline Mining & $2.376^{\mathrm{a}}$ & 3 & 0.498 \\
\hline Settlement area expansion & $18.424^{\mathrm{a}}$ & 3 & 0.000 \\
\hline
\end{tabular}

a. 0 cells $(.0 \%)$ have expected count less than 5 . The minimum expected count is 11.33 .

The direct drivers of deforestation were tested with cross tabulation, and the deforestation and forest degradation determining factors in the study area were identified (Table, 5). Accordingly, Slash and burn $(\mathrm{P}=0.01, \chi 2=15.59)$, farmland expansion $(\mathrm{P}=0.00, \chi 2=68.27)$, overgrazing $(\mathrm{P}=0.01$, $\chi 2=15.47)$, timber logging $(\mathrm{P}=0.00, \chi 2=17.88)$, firewood collection $(\mathrm{P}=0.00, \chi 2=19.47)$, charcoal production $(\mathrm{P}=0.01$, $\chi 2=16.39)$, forest fire $(\mathrm{P}=0.02, \chi 2=14.43)$, and settlement expansion $(\mathrm{P}=0.00, \chi 2=18.42)$ were significantly acted as direct causes of deforestation at $95 \% \mathrm{CI}$. This may be due to 
the reason that these drivers were as main livelihood means in the study area in their order of importance. Without having sustainable forest utilization approaches, all the above mentioned socioeconomic activities have been taking place in the woreda. The semiarid kebeles along Bilate River catchment that had been covered with Dryland forest species with diversified fauna and flora in history has been degraded seeming irreversibly. This is perceived to be as a result of continued settlement; farmland expansion, charcoal production and logging of indigenous trees, and overstocking of livestock. By its nature, these activities are not lead to environmentally friendly land use system if no other alternative livelihood strategy is designed to make the paradigm shift.

\subsubsection{Indirect Causes of Deforestation}

The indirect drivers of deforestation and forest degradation identified in the study area are presented in Figure 7. As a result, reduction of agricultural productivity (97.5\%), population growth $(98.3 \%)$, increased price of forest products $(89.2 \%)$, climate change $(97.5 \%)$, land use policy $(58.3 \%)$, lack of awareness on the forest management (96.7\%), lack of participatory forest governance $(68.3 \%)$, and lack of forest management incentives $(96.7 \%)$ were the major indirect drivers of deforestation and forest degradation. The reduction of agricultural productivity may initiate the spatial expansion of farmlands to satisfy food demand for increasing population; and may have indirectly induced deforestation. The influence of climate change on the deforestation and forest degradation are multifaceted. Climate change affects the survival and establishment of forest species, and brings failures in agricultural sector, and stimulates land encroachment for extensive production. On the other hand, increased price of forest products in nearby markets are also indirectly influenced unsustainable forest utilization of the study area. Besides to this, lack of awareness on the forest resource management and utilization trends; and lack of incentives from concerned bodies for forest management have meaningfully influenced the forest resource of the study area.

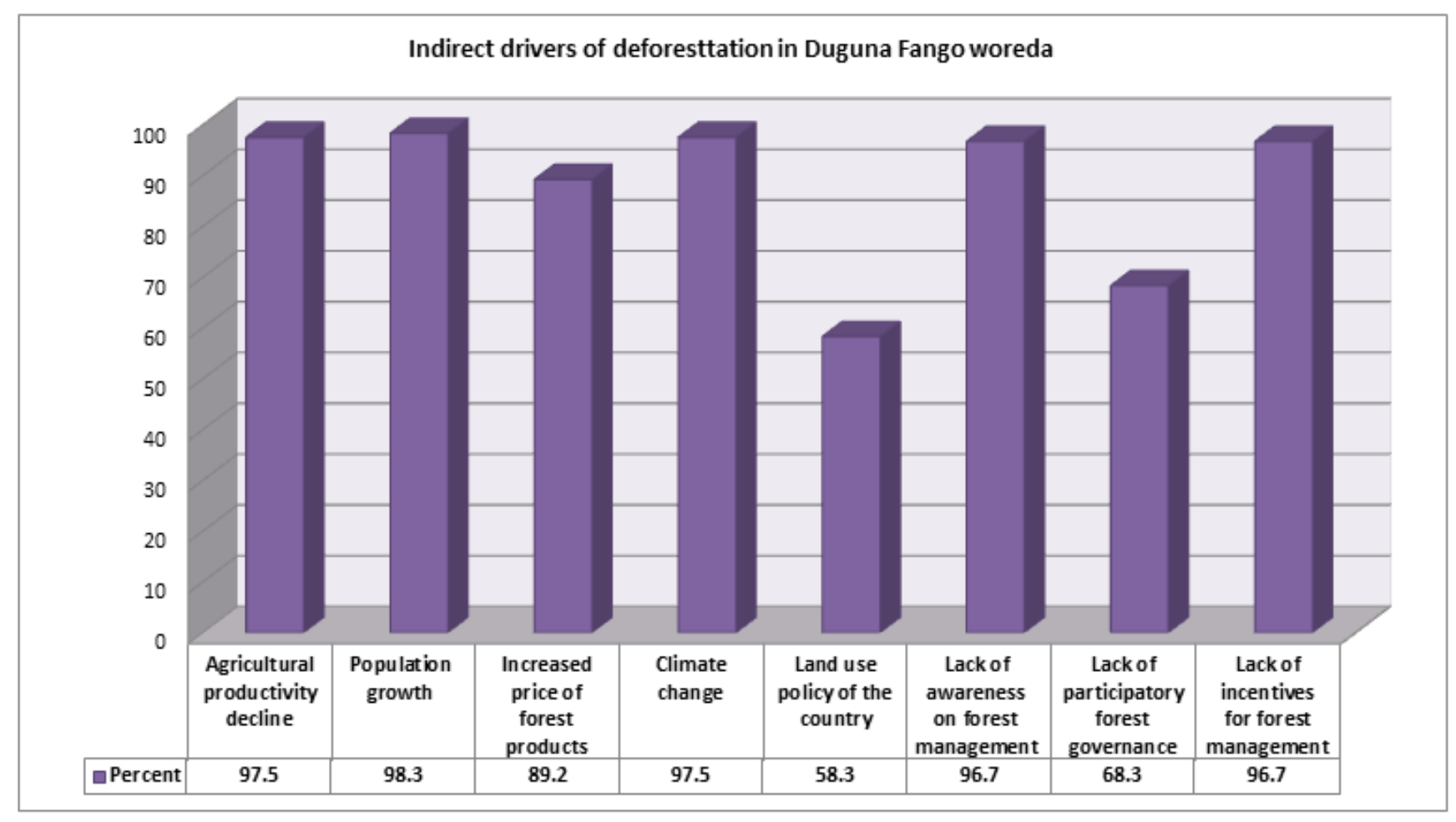

Figure 7. Indirect causes of deforestation in Duguna Fango Woreda.

The national $\mathrm{REDD}^{+}$strategy (2018-2030) in Ethiopia shows that deforestation and forest degradation are indirectly derived by: (1) absence of land use planning; (2) population pressure and rural poverty; (3) poor implementation of laws, policies and strategies; (4) inadequate incentives to various interested actors on forest investment, and (5) unclear and legitimate benefit sharing scheme, and resulting poor participation of local communities on sustainable forest management [17]. Some of these factors are reasonably true to influence the forest status of the Duguna Fango woreda.
Correlation analysis for the indirect drivers towards deforestatin and forest degrdation (Table 6) indicated that, agricultural productivity $(\mathrm{R}=20.2 \%)$ significantly correlated at $95 \%$ CI. Whereas, population growth $(\mathrm{R}=48.3 \%)$, increased price of forest products $(\mathrm{R}=38.1 \%)$, climate change $(\mathrm{R}=39.5 \%)$, and lack of awareness on the forest management $(\mathrm{R}=21.7 \%)$ significantly correlated at $99 \% \mathrm{CI}$. These factors were influenced more to deforestation and forest degradation than the other variables in Duguna Fango Woreda. 
Table 6. Correlation of indirect deforestation drivers in the Duguna Fango woreda.

\begin{tabular}{|c|c|c|c|c|c|c|c|c|c|c|}
\hline Variables & & $\begin{array}{l}\text { Agree } \\
\text { deforestati } \\
\text { on happen }\end{array}$ & $\begin{array}{l}\text { Reduction of } \\
\text { agricultural } \\
\text { productivity }\end{array}$ & $\begin{array}{l}\text { Population } \\
\text { growth }\end{array}$ & $\begin{array}{l}\text { Increased } \\
\text { price of } \\
\text { forest } \\
\text { products }\end{array}$ & $\begin{array}{l}\text { Climate } \\
\text { change }\end{array}$ & $\begin{array}{l}\text { Land use } \\
\text { policy }\end{array}$ & $\begin{array}{l}\text { Lack of } \\
\text { awareness on } \\
\text { the forest } \\
\text { management } \\
\end{array}$ & $\begin{array}{l}\text { Lack of } \\
\text { participatory } \\
\text { forest } \\
\text { governance } \\
\end{array}$ & $\begin{array}{l}\text { Lack of forest } \\
\text { management } \\
\text { incentive }\end{array}$ \\
\hline \multirow{2}{*}{$\begin{array}{l}\text { Agree deforestation } \\
\text { exists }\end{array}$} & $\mathrm{PC}$ & $0.202^{*}$ & 1 & & & & & & & \\
\hline & Sig. & 0.014 & & & & & & & & \\
\hline \multirow{2}{*}{$\begin{array}{l}\text { Reduction of } \\
\text { agricultural } \\
\text { productivity }\end{array}$} & $\mathrm{PC}$ & $0.483^{* *}$ & $0.571^{* *}$ & & & & & & & \\
\hline & Sig. & 0.000 & 0.000 & & & & & & & \\
\hline \multirow{2}{*}{ Population growth } & $\mathrm{PC}$ & $0.381^{* *}$ & $0.688^{* *}$ & 1 & & & & & & \\
\hline & Sig. & 0.000 & 0.000 & & & & & & & \\
\hline \multirow{2}{*}{$\begin{array}{l}\text { Increased price of } \\
\text { forest products }\end{array}$} & PC & $0.395^{* *}$ & $0.658^{* *}$ & $0.876^{* *}$ & 1 & & & & & \\
\hline & Sig. & 0.000 & 0.000 & 0.000 & & & & & & \\
\hline \multirow{2}{*}{ Climate change } & $\mathrm{PC}$ & -0.059 & $0.338^{* *}$ & $0.596^{* *}$ & $0.625^{* *}$ & 1 & & & & \\
\hline & Sig. & 0.259 & 0.000 & 0.000 & 0.000 & & & & & \\
\hline \multirow{2}{*}{ Land use policy } & PC & $0.217^{* *}$ & $0.407^{* *}$ & $0.377^{* *}$ & $0.412^{* *}$ & $0.219^{* *}$ & 1 & & & \\
\hline & Sig. & 0.009 & 0.000 & 0.000 & 0.000 & 0.008 & & & & \\
\hline \multirow{2}{*}{$\begin{array}{l}\text { Lack of awareness } \\
\text { on the forest } \\
\text { management }\end{array}$} & PC & -0.042 & $0.311^{* *}$ & $0.536^{* *}$ & $0.505^{* *}$ & $0.352^{* *}$ & $0.533^{* *}$ & 1 & & \\
\hline & Sig. & .325 & 0.000 & 0.000 & 0.000 & 0.000 & 0.000 & & & \\
\hline \multirow{2}{*}{$\begin{array}{l}\text { Lack on participator } \\
\text { forest governance }\end{array}$} & $\mathrm{PC}$ & -0.030 & 0.126 & $0.366^{* *}$ & $0.339^{* *}$ & $0.311^{* *}$ & $0.406^{* *}$ & $0.302^{* *}$ & 1 & \\
\hline & Sig. & 0.372 & 0.085 & 0.000 & 0.000 & 0.000 & 0.000 & 0.000 & & \\
\hline \multirow{2}{*}{$\begin{array}{l}\text { Lack of forest } \\
\text { management } \\
\text { incentive }\end{array}$} & $\mathrm{PC}$ & $0.202^{*}$ & 1 & 0.124 & 0.111 & 0.098 & 0.124 & 0.089 & $0.284^{* *}$ & 1 \\
\hline & Sig. & 0.014 & & 0.088 & 0.113 & 0.143 & 0.089 & 0.166 & 0.001 & \\
\hline
\end{tabular}

*. Correlation is significant at the 0.05 level (1-tailed); **. Correlation is significant at the 0.01 level (1-tailed); Listwise N=120

\subsection{Effects of Deforestation and Forest Degradation}

Focus group discussions in the study area have shown that recently the impact of deforestation is becoming clearly visible and manifested in rainfall variability, temperature raise, crop productivity decline due to climate change and soil fertility loss, food insecurity and stunting in children. On the other hand, habitat fragmentation, and total destruction has resulted in migration and death of wildlife and another biodiversity.

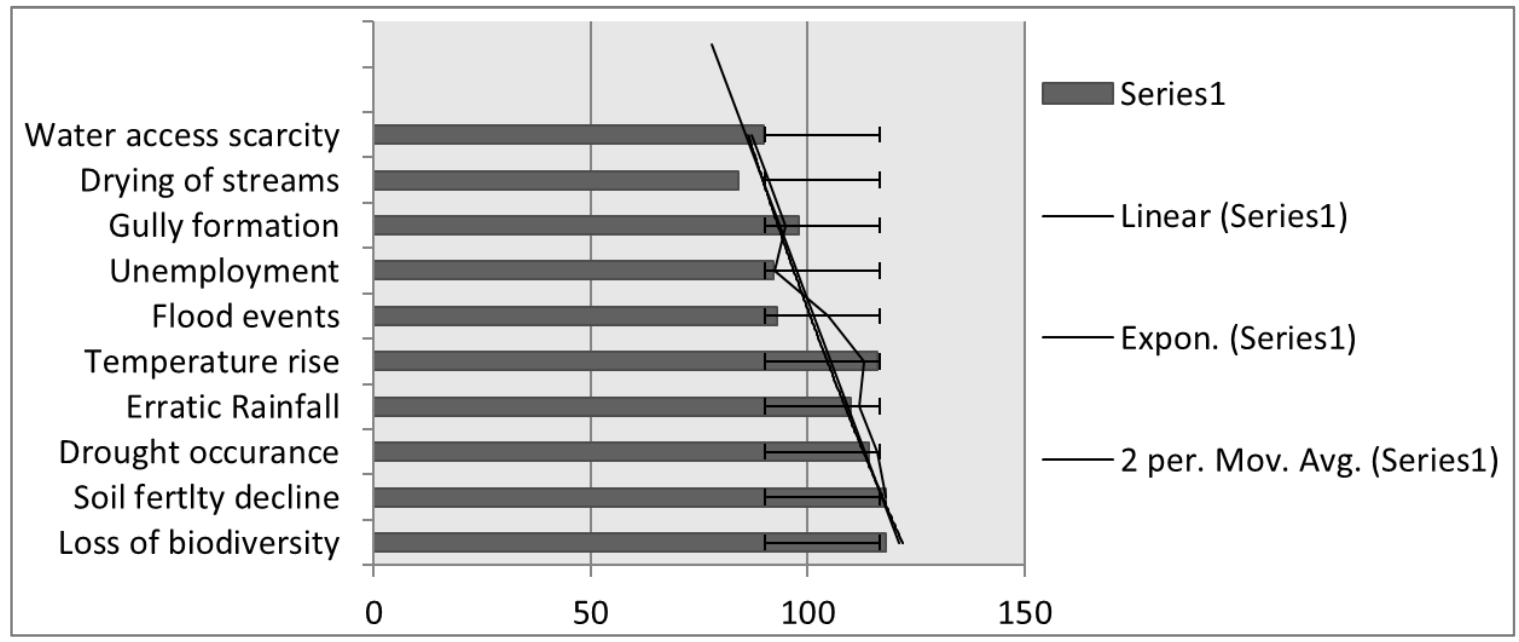

Figure 8. The impact of deforestation and forest degradation in Duguna Fango.

From the sample household heads, 119 (99.2\%) perceives that they experienced environmental change due to deforestation and forest degradation for the past years. Climate change resilience capacity of the system is getting very weak from time to time since soil fertility is declining; biodiversity both at communal and agricultural land uses is declining. Consequently, food and nutrition security are becoming alarming agenda for this community. Although the 
climate change impact is global/ region wise the adaptive capacity and resilience of a specific community determine the vulnerability status. The result of this study shows that there are changes in climatic character such as drought occurrence, temperature, and rainfall; and hydrologic parameters such as flooding streams water status and water resource availability in the last few years. Accordingly, 114 $(95 \%)$ respondents perceive that drought occurrence rate and extent is increasing, $110(91.7 \%)$ perceive erratic rainfall but with shortened growing dates, $116(96.7 \%)$ perceive as the temperature is rising, $93(77.5 \%)$ perceive the flood events becoming destructive. Consequently 84 (70\%) of the respondents indicated as the streams are getting dry and 90 (75\%) perceive as these problems lead them to have a shortage of water resources for household and animal consumption respectively. In addition, 92 (76.7\%) of the respondents believe that gulley formation, and land fragmentation as a result of soil erosion has brought other social impacts, mainly unemployment Duguna Fango wored (Figure 8). Despite this, the loss of biodiversity, soil fertility decline, drought occurrence rate and strength, torrential rainfall events but for short days and or months, and increasing temperature are considered as the highest impacts of deforestation and forest degradation in the study areas (Figure 8). The report of [4] also supports this finding, which in tropics deforestation and forest degradation produces many negative long-term environmental consequences such as global warming, biodiversity loss, and soil degradation.

The linear regression analysis (Table 7) depicted that loss of biodiversity, soil fertility decline, drought occurrence, erratic rainfall, raising temperature, and gully formation were significantly influenced by deforestation and forest degradation at $95 \% \mathrm{CI}$, and manifested the environmental and climate changes in the study area.

Table 7. Linear regression of the impact of deforestation in the study area.

\begin{tabular}{|c|c|c|c|c|c|}
\hline \multirow{2}{*}{ of Model } & \multicolumn{2}{|c|}{ Unstandardized Coefficients } & \multirow{2}{*}{$\begin{array}{l}\text { Standardized Coefficients } \\
\text { Beta }\end{array}$} & \multirow{2}{*}{$\mathbf{T}$} & \multirow{2}{*}{ Sig. } \\
\hline & B & Std. Error & & & \\
\hline (Constant) & 0.222 & 0.043 & & 5.110 & 0.000 \\
\hline Loss of biodiversity & 0.296 & 0.042 & 0.417 & 7.046 & 0.000 \\
\hline Soil fertility decline & 0.292 & 0.042 & 0.411 & 6.991 & 0.000 \\
\hline Drought occurrence & 0.053 & 0.021 & 0.127 & 2.509 & 0.014 \\
\hline Erratic rainfall & 0.054 & 0.022 & 0.164 & 2.498 & 0.014 \\
\hline Temperature increased & 0.098 & 0.028 & 0.193 & 3.443 & 0.001 \\
\hline Increased unemployment & 0.008 & 0.015 & 0.035 & 0.493 & 0.623 \\
\hline Gully formation & -0.046 & 0.017 & -0.195 & -2.667 & 0.009 \\
\hline Water bodies dry out & 0.010 & 0.020 & 0.051 & 0.502 & 0.617 \\
\hline Shortage of water & 0.008 & 0.025 & 0.038 & 0.324 & 0.746 \\
\hline
\end{tabular}

Dependent Variable: environmental and climate changes during the past 10 years due to deforestation.

The one-tiled bivariate Pearson correlation analysis for the variables concerning direct causes of deformation and forest degradation and its impacts at $95 \%$ and $99 \% \mathrm{CI}$ are indicated in Table 8. That Slash-and-burn in the natural forest areas for a different reason is positively significantly correlated with Erratic RF $(\mathrm{r}=19.1 \%)$ at 95\%, and an increase in flood events $(\mathrm{r}=23.8 \%)$ at $99 \%$ CI. Farmland expansion for crop cultivation is significantly correlated with soil fertility decline $(\mathrm{r}=19.5)$ at $95 \% \mathrm{CI}$; and increase in flood events $(\mathrm{r}=33.2 \%)$, and gulley $(\mathrm{r}=24.3 \%)$ formation at $99 \%$ CI. Livestock overgrazing is positively significantly correlated with soil fertility $(\mathrm{r}=21.1 \%)$ and temperature rise $(19.8 \%)$ at $95 \% \mathrm{CI}$, while with unemployment $(\mathrm{r}=32.2)$, Gully formation $(\mathrm{r}=37.1)$, Limitation in water access $(\mathrm{r}=29.1)$ at $99 \%$ CI. Logging for timber is positively significantly correlated to Erratic rainfall $(\mathrm{r}=20.7 \%)$, while with an Increase in flood events $(\mathrm{r}=26.5)$, and gulley formation $(\mathrm{r}=21.3 \%)$ at $99 \% \mathrm{CI}$. Uncontrolled firewood collection is positively significantly correlated with increase in temperature $(\mathrm{r}=15.9 \%)$ at $95 \% \mathrm{CI}$, whereas with biodiversity loss $(\mathrm{r}=28.3 \%)$, soil fertility decline $(\mathrm{r}=28.3 \%)$, unemployment $(\mathrm{r}=21.3 \%)$, and gulley formation $(\mathrm{r}=29.2 \%)$ at $99 \%$ CI. Charcoal production is positively significantly correlated to gulley formation $(\mathrm{r}=20.1 \%)$ at $95 \% \mathrm{CI}$ while with Soil fertility decline $(\mathrm{r}=21.6 \%)$, unemployment $(\mathrm{r}=38 \%)$, Drying of streams $(\mathrm{r}=22.2 \%)$ and Limitation in water access $(\mathrm{r}=30.5 \%)$. Forest fire is positively significantly correlated to drying of streams $(r=16.3 \%)$ at $95 \% \mathrm{CI}$, and unemployment at $(\mathrm{r}=24.9 \%)$ at $99 \% \mathrm{CI}$.

Table 8. Pearson correlation of direct causes of deforestation Vs its effect in the study sites.

\begin{tabular}{|c|c|c|c|c|c|c|c|c|c|c|c|}
\hline variables & & Loss BD & $\begin{array}{l}\text { Soil fertility } \\
\text { decline }\end{array}$ & $\begin{array}{l}\text { Drought } \\
\text { occur }\end{array}$ & $\begin{array}{l}\text { Erratic } \\
\text { RF }\end{array}$ & $\begin{array}{l}\text { Increase } \\
\text { in Temp. }\end{array}$ & $\begin{array}{l}\text { Increase in } \\
\text { flood events }\end{array}$ & Unemployment & $\begin{array}{l}\text { Gully } \\
\text { formation }\end{array}$ & $\begin{array}{l}\text { Drying of } \\
\text { streams }\end{array}$ & $\begin{array}{l}\text { Limitation in } \\
\text { water access }\end{array}$ \\
\hline \multirow{2}{*}{ Slash-and-burn } & $\mathrm{PC}$ & 0.004 & 0.135 & -0.069 & $0.191^{*}$ & 0.099 & $0.238^{* *}$ & -0.139 & 0.059 & -0.051 & -0.058 \\
\hline & Sig. & 0.481 & 0.071 & 0.227 & 0.018 & 0.141 & 0.004 & 0.065 & 0.261 & 0.290 & 0.265 \\
\hline \multirow{2}{*}{$\begin{array}{l}\text { Farmland } \\
\text { expansion }\end{array}$} & $\mathrm{PC}$ & 0.054 & $0.195^{*}$ & -0.070 & 0.125 & 0.077 & $0.332^{* *}$ & 0.144 & $0.243^{* *}$ & -0.083 & -0.094 \\
\hline & Sig. & 0.279 & 0.016 & 0.222 & 0.087 & 0.201 & 0.000 & 0.059 & 0.004 & 0.185 & 0.154 \\
\hline \multirow{2}{*}{ over grazing } & $\mathrm{PC}$ & 0.066 & $0.211^{*}$ & 0.030 & 0.084 & $0.198^{*}$ & 0.026 & $0.322^{* *}$ & 0.046 & $0.371^{* *}$ & $0.291^{* *}$ \\
\hline & Sig. & 0.238 & 0.010 & 0.373 & 0.180 & 0.015 & 0.390 & 0.000 & 0.310 & 0.000 & 0.001 \\
\hline $\begin{array}{l}\text { Logging for } \\
\text { timber }\end{array}$ & Sig. & 0.453 & 0.062 & 0.149 & 0.012 & 0.119 & 0.002 & 0.472 & 0.010 & 0.161 & 0.300 \\
\hline
\end{tabular}




\begin{tabular}{|c|c|c|c|c|c|c|c|c|c|c|c|}
\hline variables & & Loss BD & $\begin{array}{l}\text { Soil fertility } \\
\text { decline }\end{array}$ & $\begin{array}{l}\text { Drought } \\
\text { occur }\end{array}$ & $\begin{array}{l}\text { Erratic } \\
\text { RF }\end{array}$ & $\begin{array}{l}\text { Increase } \\
\text { in Temp. }\end{array}$ & $\begin{array}{l}\text { Increase in } \\
\text { flood events }\end{array}$ & Unemployment & $\begin{array}{l}\text { Gully } \\
\text { formation }\end{array}$ & $\begin{array}{l}\text { Drying of } \\
\text { streams }\end{array}$ & $\begin{array}{l}\text { Limitation in } \\
\text { water access }\end{array}$ \\
\hline \multirow{4}{*}{$\begin{array}{l}\text { Firewood } \\
\text { collection } \\
\text { Charcoal } \\
\text { production }\end{array}$} & $\mathrm{PC}$ & $0.283^{* *}$ & $0.283^{* *}$ & -0.005 & -0.060 & $0.159^{*}$ & 0.014 & $0.213^{* *}$ & $0.292^{* *}$ & 0.034 & 0.038 \\
\hline & Sig. & 0.001 & 0.001 & 0.478 & 0.259 & 0.042 & 0.438 & 0.010 & 0.001 & 0.358 & 0.340 \\
\hline & $\mathrm{PC}$ & 0.069 & $0.216^{* *}$ & -0.052 & 0.023 & 0.098 & 0.126 & $0.380^{* *}$ & $0.201^{*}$ & $0.222^{* *}$ & $0.305^{* *}$ \\
\hline & Sig. & 0.228 & 0.009 & 0.287 & 0.403 & 0.144 & 0.085 & 0.000 & 0.014 & 0.007 & 0.000 \\
\hline \multirow{2}{*}{ Forest fire } & $\mathrm{PC}$ & -0.027 & 0.106 & $-0.203^{*}$ & -0.062 & 0.057 & 0.033 & $0.249^{* *}$ & -0.097 & $0.163^{*}$ & 0.118 \\
\hline & Sig. & 0.387 & 0.124 & 0.013 & 0.252 & 0.269 & 0.362 & 0.003 & 0.147 & 0.037 & 0.100 \\
\hline \multirow{2}{*}{ Mining } & $\mathrm{PC}$ & 0.073 & 0.073 & 0.130 & 0.100 & 0.105 & $0.164^{*}$ & 0.035 & 0.117 & 0.115 & 0.056 \\
\hline & Sig. & 0.213 & 0.213 & 0.079 & 0.139 & 0.127 & 0.036 & 0.351 & 0.102 & 0.106 & 0.271 \\
\hline \multirow{2}{*}{$\begin{array}{l}\text { Increased } \\
\text { settlement }\end{array}$} & $\mathrm{PC}$ & -0.007 & 0.124 & $0.218^{* *}$ & $0.226^{* *}$ & -0.009 & $0.193^{*}$ & -0.028 & $0.192^{*}$ & -0.033 & -0.029 \\
\hline & Sig. & 0.472 & 0.089 & 0.008 & 0.006 & 0.460 & 0.017 & 0.382 & 0.018 & 0.361 & 0.377 \\
\hline
\end{tabular}

**. Correlation is significant at the 0.01 level (1-tailed); *. Correlation is significant at the 0.05 level (1-tailed); Listwise N=120; and PC is for Pearson Correlation

\section{Conclusion and Recommendation}

Forest, the heart of glob has significantly dwindled in Ethiopia last decades before Ethiopia's government crafted to focus on tree plantation, area closure, and other watershed management activities to bring the current status of forest cover in the country. Similarly, the historically dense forest cover of Duguna Fango woreda before 1977s was lost due to various reasons. In the present scenario, deforestation is a global issue with many implications and the large forest area is being encroached, resulted in the loss of overall environmental function including vegetation quality degradation, surface runoff, and biodiversity loss.

Different socio-economic factors have aggravated deforestation and forest degradation in Duguna Fango. The sex, family size, and education level of respondents were significantly associated with the forest status of the woreda. Since forest had a direct and indirect role in the community's livelihood, the dependency on forest and forest products for both income generation and home consumption resulted in massive deforestation and forest degradation. Farmland expansion after failures of agricultural productivity, charcoal production, lack of awareness, lack of strong regulation in forest protection and others have directly and indirectly brought the historical loss of forest cover in the area.

The current socio-economic data indicated that deforestation and forest degradation in Duguna Fango woreda is not limited to but have brought loss of biodiversity, soil fertility decline, recurrent drought occurrence, erratic rainfall, the temperature increased, and gully formation. Subsequently, these factors have aggravated the community's social, economic and ecological problems such as unemployment, food and nutrition insecurity, and further land degradation and desertification.

Area closure and other land restoration activities may be implemented to restore the forest cover anywhere convenient; whereas, the day to day community demand with wood and none wood forest products may influence the effectiveness of this goal. Rather, improving forest cover of privately owned lands through agroforestry practices is a very critical solution in shifting the attention of people that previously depend on natural forests. Agroforestry, the intentional integration of trees with crops and/or livestock, can lead to multiple economic and ecological benefits compared to crops/livestock grown separately [18]. Side by side to restore open and highly degraded areas through tree plantation or area closure, fruit, food, and fodder product-oriented multipurpose tree species introduction to private landowners has ecological, economic benefits together. The community tree species preference was identified, and trees used for soil and water conservation, fodder trees for animal feed, timber trees, and trees used for fuelwood purpose were highly preferable tree types for the Duguna Fango community. Hence, through this process, it can be possible to gradually minimize the pressure on natural vegetation and let restore the lost legacy of forest cover of the study areas.

Finally, awareness creation on sustainable forest management, the establishment of participatory forest management programs with a full package of role and responsibility for the community members while maximizing the number of indigenous tree planting and area exclosure is needed. Meanwhile, establishing legal binding rules on the management of forest is suggested for communal forest lands in the study area. Furthermore, as it can sufficiently afford food, wood and fodder, agroforestry system based land management has to be introduced to the woreda as a potential forest loss harnessing opportunity.

\section{Acknowledgements}

The authors would like to thank UNDP, Green Economy fund, Government of Ethiopia, Wolaita Sodo University and Duguna Fango Woreda for providing this golden opportunity to do this wonderful project through funding and logistic support. We are also immensely grateful to communities and field assistants to access and collect field data. We hereby declare that all the information and statements made in this research are true and accept that any misinterpretation contained in it may be our obstructions.

\section{References}

[1] FAO (2006). Global Forest Resource Assessment 2005: Progress towards Sustainable Forest Management. FAO, Rome.

[2] WBISPP (2005). A national strategy plan for the biomass sector. Addis Ababa, Ethiopia. 
[3] FAO (2010). Global Forest Resources Assessment 2010 Country Report: Ethiopia, FRA2010/065, FAO, Rome.

[4] Mahapatra, K. and Kant, S. (2003). Tropical Deforestation: A Multinomial Logistic Model and some Country-specific Policy Prescriptions, Journal of Forest Policy and Economics, Elsevier, 7: 1-8.

[5] Wilkie, D., Shaw, E., Rotberg, F., Morelli, G. and Auzels, P. (2000). Roads, development and Conservation in the Congo Basin. Conservation Biology, 14: 1614-1622.

[6] Amor, D. (2008). Road impact on deforestation and jaguar habitat loss in the Selva Maya. Ph.D. dissertation. Ecology Department, Nicholas School of the Environment, Duke University, Durham, NC, USA

[7] Amor, D. and Pfaff, A. (2008). Early history of the impact of road investments on deforestation in the Mayan Forest. Working Paper, Nicholas School of the Environment and Sanford School of Public Policy, Duke University, Durham, NC, USA.

[8] Adams, W. M. (2009). Green Development: Environment and Sustainability in the Third World, 3rd Edition, Routledge, London and New York.

[9] Repetto, R. (1988). The forest for the trees? Government policies and the misuse of forest resources. World Resource Institute, Washington DC.

[10] Rowe, R.; Sharma, N. P. and Bowder, J. (1992). Deforestation: problems, causes and concern. In: Managing the world's forest: looking for balance between conservation and development, ed. Sharma, N. P. Kendall/Hunt Publishing Company, Iowa. 33-46.

[11] Wikipedia contributors. (2019, April 10). Duguna Fango. In
Wikipedia, The Free Encyclopedia. Retrieved 11:18, June 30, 2019, from https://en.wikipedia.org/w/index.php?title=Diguna_Fango\&ol $\operatorname{did}=891849632$

[12] WZFEDD (Wolaita Zone Finance and Economic Development Department) (2015): Zonal basic socioeconomic and demographic information, Wolaita Sodo.

[13] Chernet, D. (2015). Micro Watershed Development Using GIS \& Remote Sensing in the Case of Chille and Ocholo Watersheds, Duguna Fango Woreda, Wolaita Zone, Southern Nations Nationalities and Peoples Region, Ethiopia. Journal of Environment and Earth Science, 8 (2): 39-47.

[14] Kothari, C. R. (2004). Research Methodology Methods \& Techniques 2nd Edition. New Delhi, India. New Age International (P) Limited.

[15] Beyene, K. K. (2011). Soil Erosion, Deforestation and Rural Livelihoods in the central Rift Valley Area of Ethiopia: A Case Study of the Denku Micro-Watershed Oromia Region published Master's thesis, June 2011, University of South Africa: 13-14.

[16] Haggett, P. (2001). Geography: A Global Synthesis; Pearson Education Limited, Upper Saddle River, New Jersey 07458: 321-349.

[17] National REDD+ Strategy (2018-2030) Federal Democratic Republic of Ethiopia. Ministry of Environment, Forest and Climate Change National REDD+ Secretariat, June 2018. 74p.

[18] FAO (2017). Agroforestry for landscape restoration: Exploring the potential of agroforestry to enhance the sustainability and resilience of degraded landscapes. FLRM, Rome, 2017, 28pp. 